\title{
Technological change and opportunities for development as a moving target
}

\section{Carlota Pérez}

Honorary Research Fellow, SPRU, the University of Sussex.

Adjunct Senior Research Fellow, INTECH, United Nations

University

The Netherlands

carperez@reacciun.ve
This article puts forward an interpretation of development

as a process of accumulation of technological and social capabilities dependent upon taking advantage of successive and different windows of opportunity. These windows are determined from the core countries, through the technological revolutions which occur every half-century and the four phases of their deployment. The possibilities of progressing at each opportunity depend on the achievements made in the previous phase, on identifying the nature of the next one, understanding the technoeconomic paradigm of the revolution in question, and being able to design and negotiate, in each case, a positive-sum strategy, taking account of the interests of the most powerful firms. On the basis of this interpretation, a summary review is made of the successive development strategies applied since the $1950 \mathrm{~s}$. The author then outlines the likely nature of the next phase and, applying the principles of the current techno-economic paradigm, explores some aspects of the institutional changes to be carried out. 


\section{I}

\section{Technological change and development}

Technology is usually seen as a specialized field of development policy, with separate institutions. In this study, however, we maintain that, rather than being merely an element of development strategies, technology is a condition for their viability. The opportunities for development are a moving target. Any serious observer of the progress made in terms of development from the late 1950s to the late 1970s must acknowledge that the import substitution strategies applied by various countries resulted in gradual but significant advances. In the mid-1970s, when the combination of the industrial redeployment from the North with export promotion from the South showed and promised new and broader advances, there was hope that progress would be constant. With the failure and subsequent deterioration of the model based on protection and subsidies in most of the countries which tried to keep on applying it, the pendulum has swung to the other extreme, so that all the achievements previously made with that model are now denied. This has provided fertile ground for advocating the free market as the only way of achieving satisfactory results in terms of development, even though the efficacy of that policy has not yet been proven.

This article maintains that development opportunities arise and undergo changes as the successive technological revolutions are deployed in the advanced countries. Technology and production equipment are only transferred voluntarily when they hold out the promise of mutual benefits. The import substitution strategies were successful because they represented a positive-sum game for the mature industries of the developed world, which were coming up against technological exhaustion and market saturation. With the eruption of the information revolution, however, these conditions radically changed and other viable options opened up.

Based on this interpretation, this article examines development strategies from a different angle, which can be especially useful as regards the challenges of the globalization process and the information era. Firstly, it analyses the evolution of technologies, in order to understand in what conditions development opportunities are created and to determine their nature. It then goes on to address the question of development as a way of learning to take advantage of these changing opportunities. This is illustrated through a review of the successive development models applied in the last 50 years and an examination of the challenges raised by the next stage of concentration of power in the world economy. Finally, some of the institutional requirements for coping with the new "flexible networks paradigm" are studied.

\section{II}

\section{The product cycle, development and changes in barriers to entry}

The role played by imported technology as a mandatory stage on the road to industrialization is a fact that is known historically from the experience of the United

$\square$ This study was originally prepared for UNCTAD $\mathrm{x}$ and was subsequently presented at the seminar on development theory at the dawn of the twenty-first century, organized by ECLAC in Santiago, Chile, to commemorate the centenary of the birth of Raúl Prebisch.
States and various European countries in the nineteenth century and the early twentieth. More recently, this role has been confirmed by the rapid transformation of Japan into a first-line country and the big advances made by the four "Asian tigers". The success of these countries has undoubtedly been due to the absorption of technology from the most advanced countries and their own efforts to adopt, adapt, modify and master the 


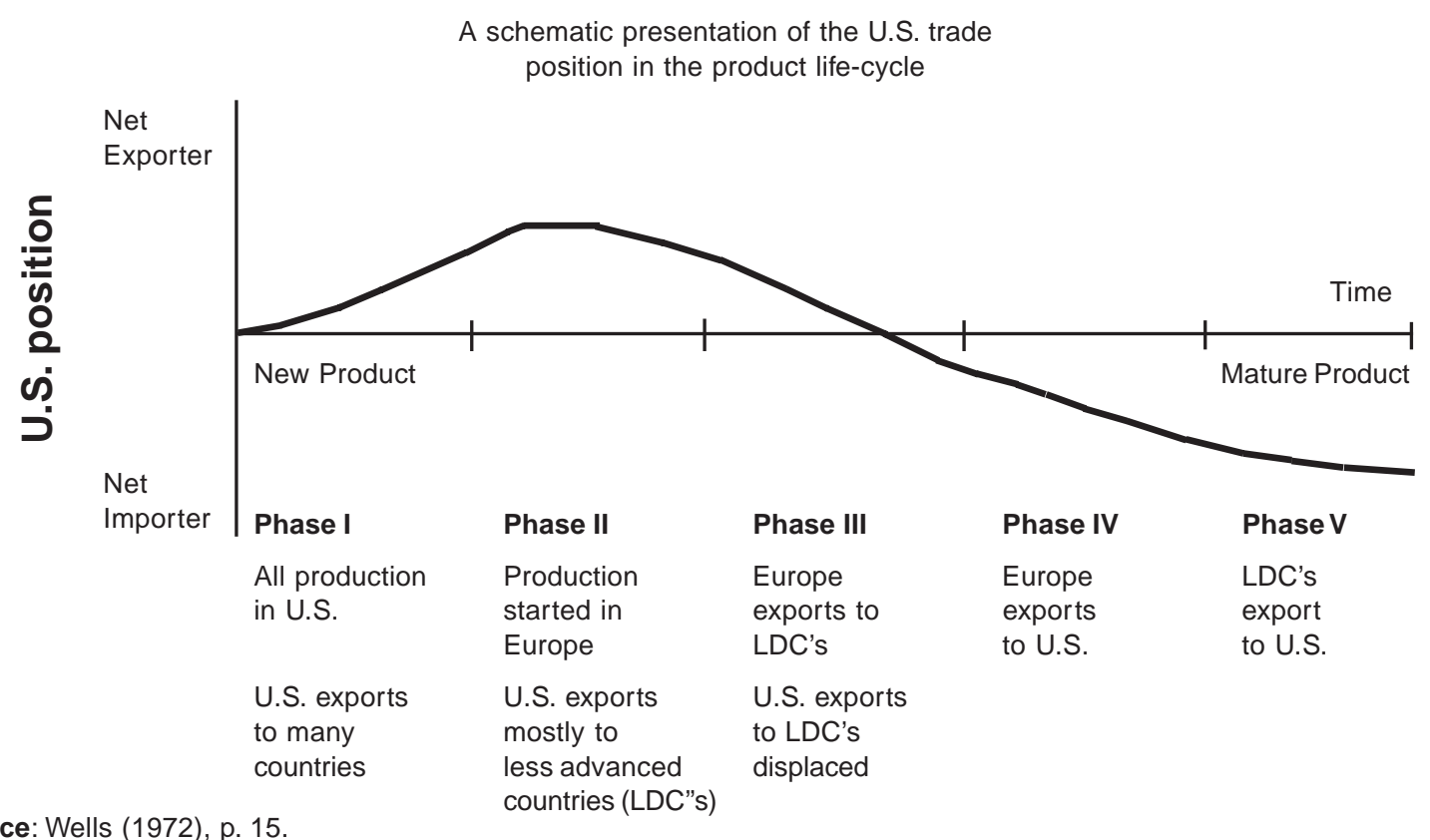

Source: Wells (1972), p. 15.

corresponding technical know-how (Freeman, 1987; Amsden, 1989). However, many more examples can be cited of countries which had little success in promoting their development over the same period, even though they apparently applied similar procedures for making use of imported technology. Furthermore, many countries and even whole regions -such as Africa and most of South America- seem to have lost much of the ground previously won (Mytelka, 1989; Katz (ed.), 1996).

The reasons for such different results are to be sought partly in the specific policies applied in each case and partly in the particular conditions of each country. At a deeper level, these reasons are connected with the nature of the windows of opportunity created by the technological evolution of the leading countries and the capacity for consciously or intuitively taking advantage of them. This makes it necessary to consult the abundant specialized literature on the ways in which technologies evolve and diffuse.

\section{The product life cycle and the geographic propagation of technologies}

One of the first attempts to analyse the technological possibilities of the developing countries was made by Hirsch (1965). By examining the behaviour of the traditional electronics industry in terms of the product cycle, Hirsch showed how the advantages shift in favour of the less advanced countries when technologies approach maturity. Wells (1972) graphically summarized the process for the case of the United States, in his study of the literature on the product cycle (figure 1).

The migration of production, first from the country of origin to other advanced countries and later to less developed countries, revealed one of the processes behind the paradox observed by Leontief, whereby the exports of the United States had a higher labour content than its imports (Leontief, 1954). This situation, which was unexpected for the leading country in matters of technology, is related with the changing characteristics of evolving technologies. Technologies tend to make more intensive use of labour in their initial phases and to use relatively costly personnel with high levels of knowledge and qualifications. ${ }^{1}$ When they approach maturity, however, they are using highly standardized, mechanized and automated processes.

When technologies mature, there are forces which push them out more and more towards the periphery, where, presumably, there are complementary forces that pull them in order to set development processes in

${ }^{1}$ See Hirsch (1965 and 1967), Vernon (1966) and, more recently, Von Tunzelmann and Anderson (1999). 
motion. Although this observation applies above all to consumer goods and some basic capital goods, the range of products covered is wide enough to serve as a starting point for the analysis.

\section{With mature technologies there can be no catching up ${ }^{2}$}

It is ironic that advantages are shifting in favour of capital-poor countries precisely when the production process is marked by more intensive use of capital. When this phase has been reached, tasks have become so routine - see phase 4 in figure $2-^{3}$ that production does not require much prior know-how or experienced managers, while the processes can use unskilled labour. As technology and markets reach maturity, the determining advantage is the comparative cost profile.

Can there be a catching-up process in development based on mature technologies? This is extremely unlikely, for various reasons. As shown in figure 3, mature technologies reach a point where they have only minimal potential for producing profits, face stagnant markets, and have almost no room left for improving productivity. Thus, generally speaking, using the maturity phase as a starting point is costly and is neither

FIGURE 2

Changing entry requirements as technologies evolve to maturity

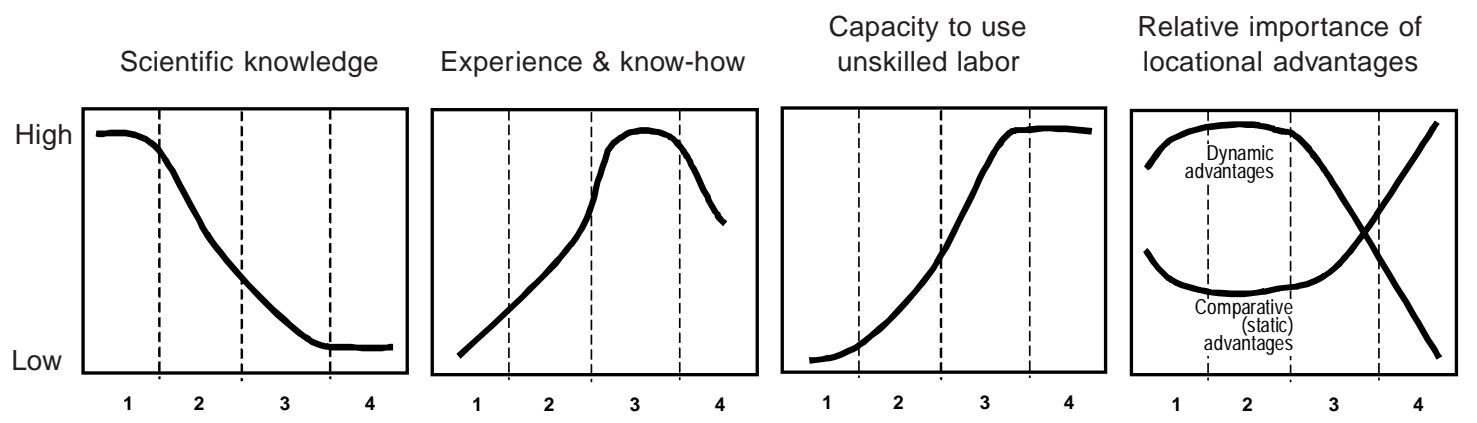

Source: Based on Perez and Soete (1988) and Hirsch (1967).

FIGURE 3

Changing potential of technologies as they evolve to maturity

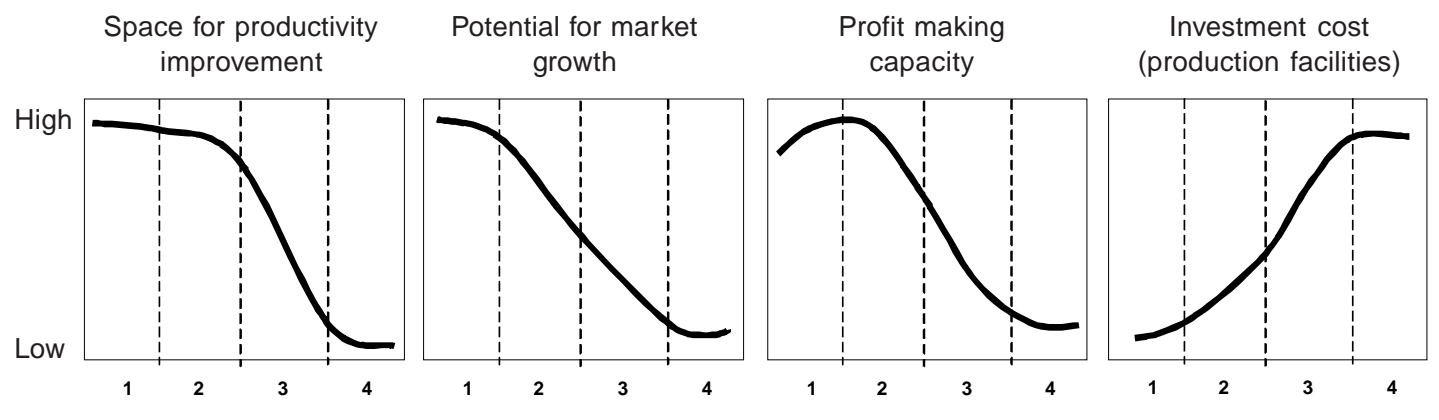

Source: Based on Gerschenkron (1962), Cundiff and others (1973), Kotler (1980) and Dosi (1982).

${ }^{2}$ This section is based on Pérez and Soete (1988).

\footnotetext{
${ }^{3}$ It may be considered that phase 4 approximately covers phases IV and V in Wells's diagram (see figure 1).
} 
very profitable nor very promising. Even so, it is probably the best starting point for creating a basic industrialization platform, generating learning capacity, and establishing the basic infrastructure and other externalities needed to back up a development effort.

However, catching-up supposes a dynamic development process, fuelled by local innovation and growing markets. This requires an entry as early as feasible. Surprisingly enough, apart from the mature phase of technologies, the other moment when weaker players confront surmountable barriers is not in phases two or three but rather in phase one. This happens to be the most promising entry point, because, as indicated in figure 3, potential profits are high, there is ample space for market and productivity growth and investment costs are relatively low. Even research and development investment, can often be lower than that of the original innovator.

It might be thought that only the enterprises of advanced countries can possess the high level of knowledge required in this phase (see figure 2). However, if the new products belong to the early phases of a technological revolution, the know-how involved tends to be in the public domain (available in universities, for example). An example of this is the recent case of Silicon Valley and its thousands of successful imitators all over the world. In these cases, the prior experience required is not very great, and indeed, possessing it may even be a disadvantage, because technological revolutions impose new management models which make the previous ones obsolete.

The other restrictive factor is connected with the surrounding environment. Success in using new technologies depends on certain important complementary factors, such as dynamic advantages and different types of externalities, especially the physical, social and technological infrastructure or the existence of competent and demanding local clients. These elements may have been built-up before with mature technologies, or they can be acquired through intensive learning processes and investments in the improvement of the social and economic environment.

It would appear, then, that a strategy could be designed for accumulating technological and social capabilities through the use of mature technologies and then making use of that base for gaining access to new and dynamic technologies, but this possibility depends to a large extent on the specific opportunities created by the successive technological revolutions. A full understanding of the way technology evolved in the advanced countries could be useful for developing countries wanting to design viable strategies. This is the subject of the following section.

\section{III}

\section{Technologies, systems, revolutions and paradigms}

The evolution of technology is a complex process; technologies are interconnected in systems, and these, in turn, are intertwined and interdependent, both with each other and in relation to the physical, social and institutional environment.

Much of technological learning is gradual and incremental. However, there is no inevitable progression towards an ever more advanced and always unattainable frontier. There are important discontinuities which become windows through which latecomers can leap forward. These opportunities occur in the form of technological revolutions and involve sharp changes of direction in technological progress; they also provide the means for modernizing most activities at the cost of abandoning much of the management know-how previously accumulated and part of the previous equipment, along with the related specialized knowledge. New technologies of a revolutionary nature open up new opportunities for learning and catchingup. The interaction of continuous and discontinuous technological changes explains why and how windows of opportunity for development vary with time.

\section{Technological trajectories and the accumulation of experience}

In spite of their specific differences, most technologies tend to follow a similar trajectory as regards the rate and direction of change and improvement, from initial innovation to maturity. This evolution more or less 
FIGURE 4

The evolution of a technology: A technological trajectory

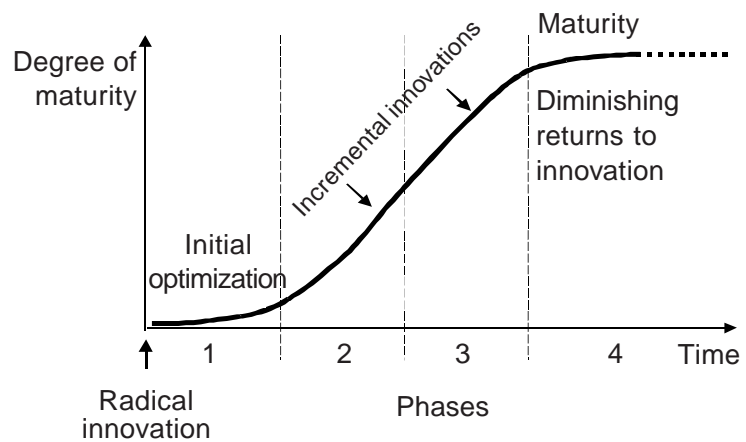

Source: Based on Nelson and Winter (1977), Dosi (1982), Freeman and Pérez (1988), Wolf (1912), Abernathy and Utterbak (1975), and other authors.

coincides with that of their markets: from introduction to saturation 4 (figure 4).

After a radical innovation gives rise to the appearance of a new product, capable of generating a new industry, there is an initial period of intensive innovation and optimization, until the product gains acceptance in the corresponding market segment. Interaction with the market soon determines the direction that improvements will take, and these often define a dominant design (Arthur, 1989; David, 1985). From that point on, as the markets grow, successive incremental innovations are made to improve the quality of the product, the productivity of the processes, and the producers' market position. This process culminates in maturity, when new investment in innovations begins to have diminishing returns. Depending on the importance of the product, the whole process can last a few years or a number of decades. In the latter case, the "improvements" usually take the form of successive models.

After the first innovations, the firms developing the technology acquire advantages, not only through patents but also -and perhaps more importantlythrough the experience accumulated with product, process and markets. This tends to keep the corresponding general and specialized know-how in the

\footnotetext{
${ }^{4}$ Abernathy and Utterback (1975), Dosi (1982) and Sahal (1985). Among textbooks on business management, special mention may be made of Cundiff and others (1973) and Kotler (1980). An extensive summary is given in Coombs and others (1987) and Dosi (1988). A full interpretation of the relations between technology, the economy and policies is given in the classic work by Freeman (1974) on the economics of innovation and in the updated version by Freeman and Soete (1997).
}

FIGURE 5

\section{Shortening of cycles of late innovations: Spread of successive technologies in the United States automobile industry}

Percentage of output incorporating the innovation

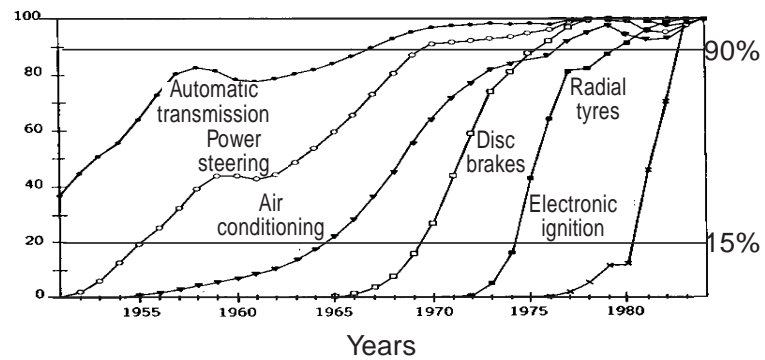

Source: Jutila and Jutila (1986), cited in Grübler (1990), p. 155.

hands of the producers and their suppliers, making it less and less accessible to new entrants. This experience also speeds up the adoption of innovations, so that the last ones are incorporated very rapidly and it is even more difficult for latecomers to catch up with the leaders (see figure 5, which illustrates this phenomenon, taking the example of the successive innovations in automobiles).

\section{Technological systems and the creation of social capabilities}

Technologies are not developed in isolation, but are connected with each other in systems, giving each other mutual support and taking advantage of experience, the development of suppliers, consumer education and other externalities created by their predecessors in the system (Freeman, Clark and Soete, 1982).

Technological systems evolve along similar lines to those of individual products (figure 4). New products represent incremental improvements in the system. In the first two phases there are many really important products with a long life cycle; afterwards, they tend to go down in number and importance, until the last ones are less significant and have a short life cycle (such as disk brakes and radial tires in figure 5).

Figure 6 presents a stylized example of the technological system of household electrical appliances, beginning with refrigerators, washing machines and vacuum cleaners and later expanding to a series of new products and successive models of earlier products. Both tend to reach maturity more or less simultaneously, together with the introduction of the last minor 
FIGURE 6

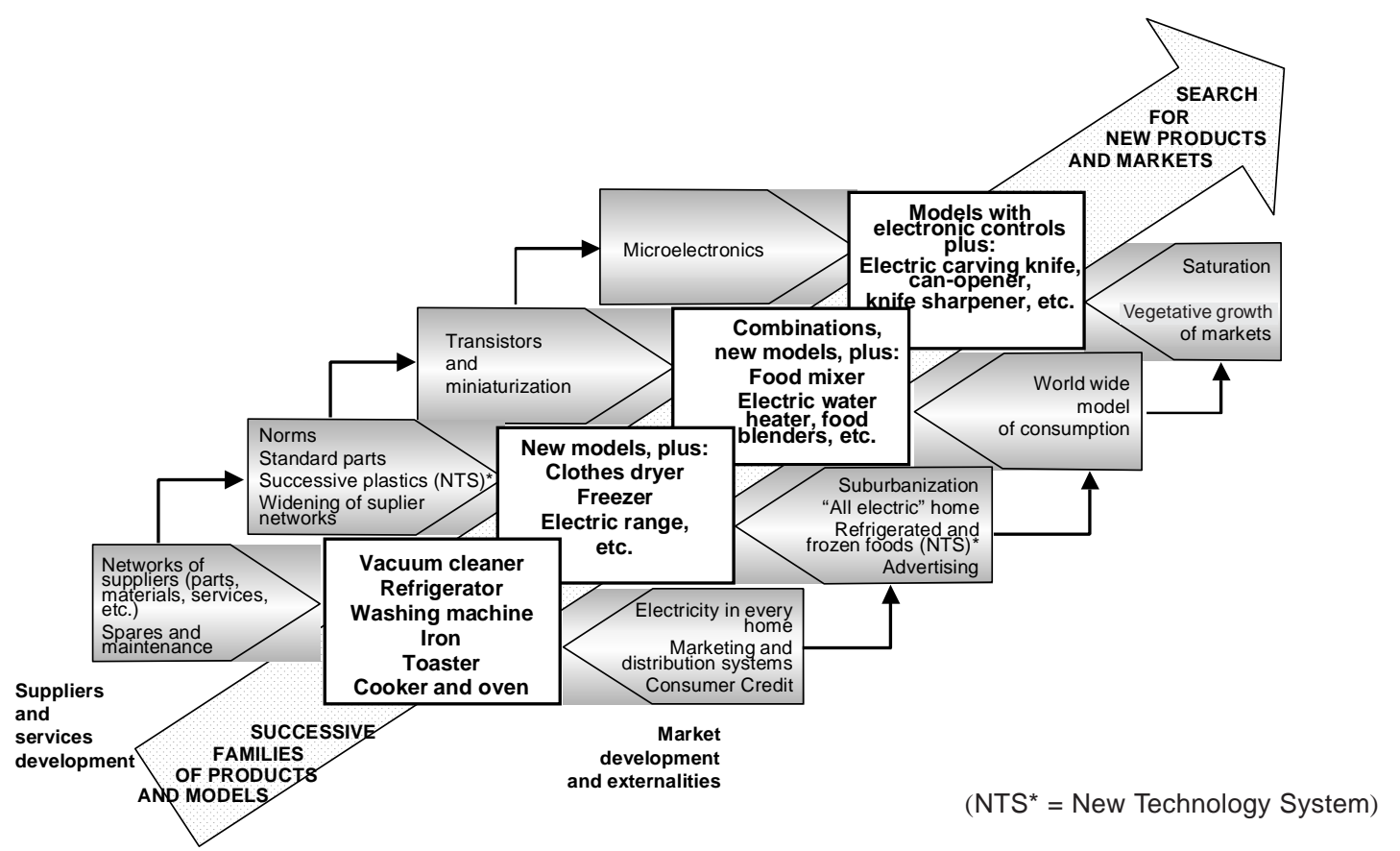

innovations of the system, such as electric can openers and carving knives. The figure also shows how the systems become established in particular territories, thanks to the extension of the network of suppliers of parts and services and the gradual establishment of regulatory frameworks and other institutional facilitators.

This growing interaction of "hard" and "soft" elements is one of the aspects that Abramovitz (1986) was referring to when he criticized the concept of development as the simple accumulation of capital and labour, stressing the need to acquire social capabilities. It is also related to the notion of national or regional systems of innovation formed by the interacting agents (Freeman, 1993; Lundvall, 1988 and 1992).

The need to form these complex networks of mutually supportive activities and institutions explains some of the limitations that development encounters when it is based on the transfer of mature technologies. It also gives support to the arguments of those who recommend building upon the traditions, local capacity and knowledge existing in each particular territory (Porter, 1991). Finally, it also shows the type of action needed to effectively support the survival of pioneering firms in developing countries.

\section{Technological revolutions and the interconnection of systems ${ }^{5}$}

Each technological revolution is a set of technology systems which gradually create the necessary conditions for the appearance of new systems, all following similar principles and obtaining benefits from the same externalities. Figures 7 and 8 illustrate two of these explosions of new technologies: the mass production revolution, with its successive systems, which crystallized around 1910 and reached maturity in the 1960s and 1970s, and the information revolution, which has been propagating since the 1970 s.

The process of multiplication of innovations and technological systems, both up and downstream from the industries that form the core of each technological revolution, explains the enormous growth potential possessed by each of these constellations of new technologies. This process represents the opening up of a vast new territory for innovation, expansion and growth. The initial innovations correspond to the

\footnotetext{
${ }^{5}$ Freeman and Pérez (1988). An extended analysis of each of these revolutions, since the original Industrial Revolution in England, may be found in Freeman and Louçã (2001).
} 
FIGURE 7

The mass production revolution: A growing network of

technological systems which spread out from 1910 on

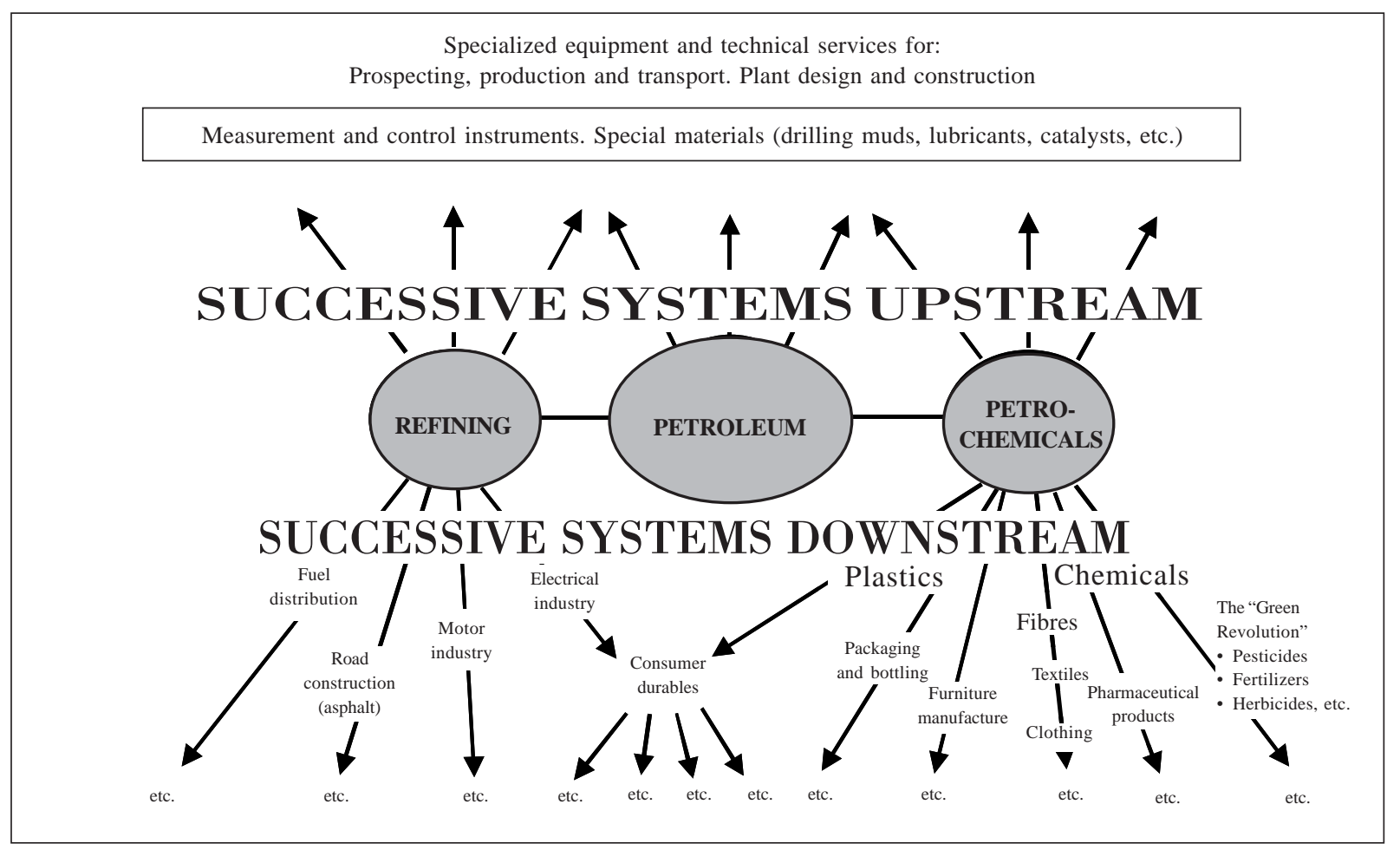

FIGURE 8

The information revolution: A growing network of technological systems which spread out from 1970 on

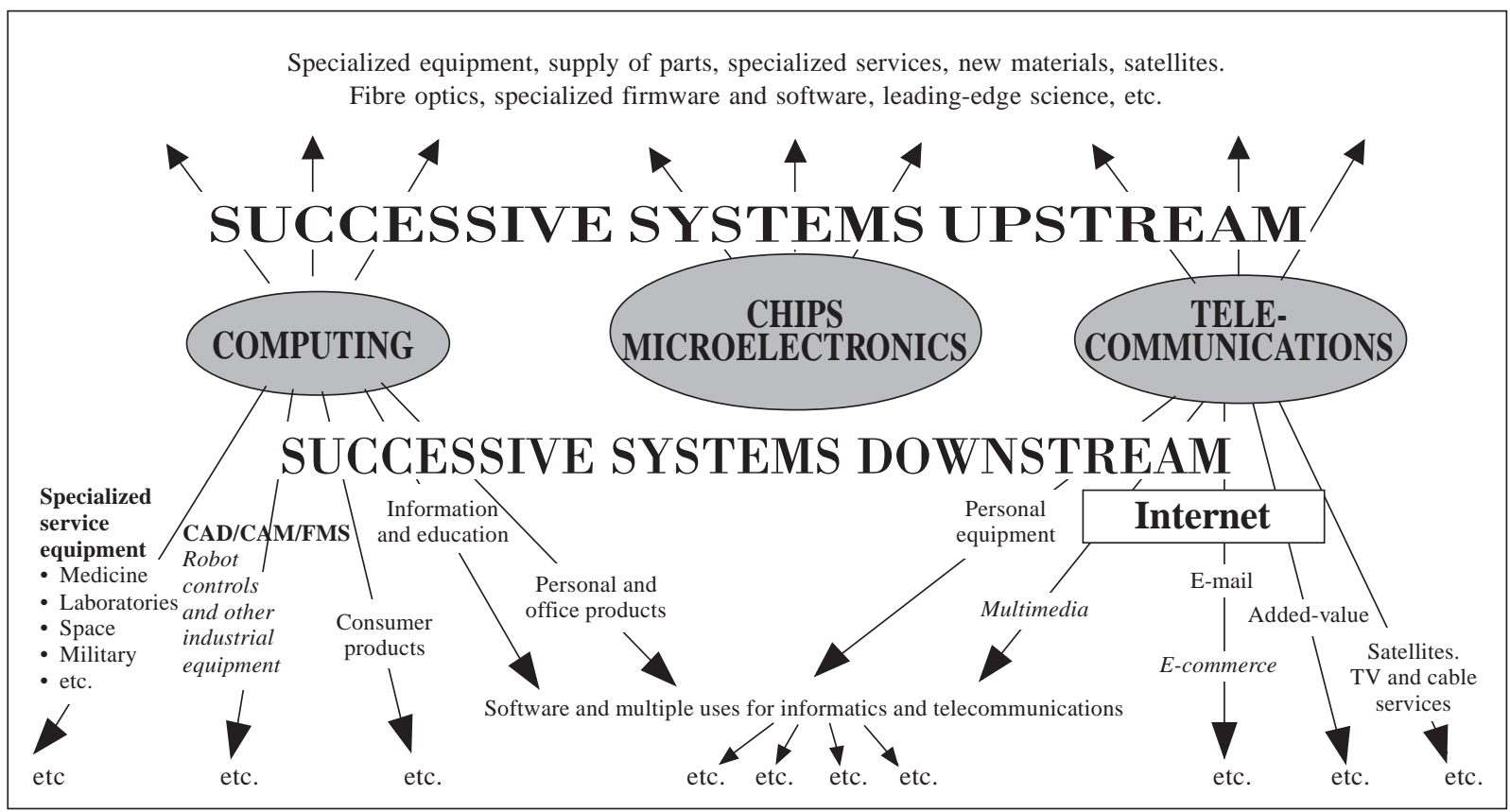


"discovery" of this territory, while the phase of maturity and exhaustion corresponds to its total "occupation".

Figures 4 and 5, with a longer time scale, may also be interpreted as the life trajectory of a technological revolution. In this case, the incremental "improvements" would be the successive new technology systems. As in the previous cases, in the early period of growth many major systems make their appearance, but as the process advances towards maturity the new systems tend to be fewer and less significant.

\section{Techno-economic paradigms and the rejuvenation of all activities}

Existing mature industries neither remain unchanged nor passively coexist with the new industries. Each technological revolution brings generic and allpervasive technologies, together with new organizational practices, which significantly increase the potential productivity of most existing activities. The principles on which this modernizing process is based are gradually incorporated into a best-practice model which we have called the "technological style" or "techno-economic paradigm". 6 The result is the gradual rejuvenation of the whole productive structure, so that updated mature industries can again behave like new industries in terms of dynamism, productivity and profitability.

This process may explain the disappointment of those who, in the North-South Dialogue of the 1970s, cherished the hope of transferring mature industries to the developing world on a permanent basis. Since the 1980s, one industry after another has been modernized: even such a traditional activity as the clothing industry has been rejuvenated and placed on an innovative course, with segmented markets (Hoffman and Rush, 1988; Mytelka, 1991).

\section{Change of paradigm as a change in management common sense}

A techno-economic paradigm articulates the technical and organizational models to take the fullest advantage of the potential of the corresponding technological revolution. Each paradigm provides a new set of "common sense" principles which serve to guide the decision-making of entrepreneurs, innovators, managers, administrators, engineers and investors towards the greatest efficiency and efficacy in both old and new activities. For those who had obtained satisfactory results with the previous paradigm, the process of adopting a new one may be devastating, for as well as demanding the abandonment of a body of experience acquired with great effort, it is as if the world had been turned upside down (Peters, 1989; Coriat, 1991).

Figure 9 shows how, with the transition from the mass production model to the flexible networks model, management criteria are changed in all fields, from product selection and design to organizational structures, forms of operation, and personnel relations.

Such phenomena as globalization and the tendency to political decentralization are also closely related with the change of paradigm, with the new possibilities it offers, and the most effective way of taking advantage of them. It may be considered that the Schumpeterian description of technological revolutions as processes of "creative destruction" is applicable not only to the economy but also to policies and institutions. ${ }^{7}$

The process of change is not easy, and the transition to the new practices may take two or three decades. Finally, however, the new paradigm becomes accepted as general common sense and is considered the natural and normal way of doing things.

Newcomers or those who had not been successful with the previous paradigm can simply redirect their efforts towards learning the new practices, whereas the established leaders have to "unlearn" much of the old paradigm and adopt the new one. Much of the experience acquired and a considerable part of the investments made in the previous context become obsolete and have to be replaced. The renewal process is long and difficult, so the newcomers may have a certain advantage, which can be reinforced by early investment in the new infrastructure and the creation of suitable facilitating institutions.

\footnotetext{
${ }^{6}$ Pérez (1983 and 1986). The expression takes the notion of technological paradigm proposed by Dosi (1982) to describe the trajectories of individual technologies to construct a broader concept which defines a common trajectory or "meta-paradigm".
}

\footnotetext{
7 The enterprises of the developing world have had to go through a double transition, since they have also had to give up the protectionist model (see Pérez, 1996).
} 
FIGURE 9

\section{Change of paradigm}

MASS PRODUCTION MODEL

Petroleum and automobile era

Inputs and value

Intensive use of energy and raw material in products, processes, transport, etc. Tangible products

Standardized products

Mass markets

Products and markets

Personnel

One best way
Optimum routine is the goal pursued

Centralized organizations

Hierarchical pyramids

Functional departments

Rigid channels of communication

Human resources
Labour viewed as a cost
Training viewed as an expected externality

FLEXIBLE NETWORKS MODEL

Information technology era

Intensive use of information and knowledge

Saving of energy and raw materials

Intangible services and value

Diversified and adaptable products

Highly segmented markets from the basic mass product to small niches

Continuous improvement

Change is the main routine

Decentralized networks

Strategic centre

Semi-autonomous multifunctional units

Interactive communications

(vertical and horizontal)

\section{Human capital}

Labour viewed as an asset

Training viewed as an investment

A change in technological and management "common sense"

\section{Development as learning to take advantage of}

\section{changing opportunities}

The picture thus drawn in broad lines shows technological evolution as a process with periods of continuity and discontinuity deriving from the nature of competition in a capitalist system. At the microeconomic level, each radical innovation represents a discontinuity followed by continued evolution until the reduction in the possibilities of increasing productivity and profits gives rise to a search for other radical innovations. At the macrosystemic level, the successive technological revolutions irrupt in the economic system, bringing whole constellations of new products, technologies and industries. These fundamental discontinuities give rise to great surges of growth, initially in the core group of industrialized countries, where, in addition to the explosive expansion of the new industries, they also encompass and gradually rejuvenate most of the existing industries. At the end of the process, when the whole set of industries is approaching maturity, the process spreads to the periphery, while in the core countries the next great surge is already irrupting.

The developing countries are thus pursuing a moving target which not only advances all the time but also changes direction approximately every halfcentury. If autarky is dismissed as an option, then development is a question of learning to play this game of constant shifts and variations, which is also a power game.

Could this be another version of dependency theory? It undoubtedly involves a notion of North-South and centre-periphery complementarity, yet at the same time it offers the possibility of breaking the vicious circle of underdevelopment by adopting suitable policies. Those who understand the game and play it 
well could find a way of making a leap forward and catching-up. The real lessons taught by the Asian Tigers do not lie in replicable recipes but rather in understanding the specific dynamics that made development possible. For such an understanding we need to know why the most favourable conditions for advancing occur during the periods of paradigm shift.

\section{Periods of change of paradigm as dual technological opportunities}

For a period of some 20 years or more, during the transition from one paradigm to another, old technologies co-exist with new ones. Most of the mature technologies of the previous paradigm are being outstretched in an attempt to overcome the limitations on productivity and market growth by spreading out geographically in order to survive. This takes place at the same time that the new technologies are expanding, flourishing and growing rapidly, with big profit margins. This situation characterized the 1960s and 1970s in the developed countries, giving rise to centrifugal trends in which the rich, modern and successful become richer, while the poor and weak become poorer. Paradoxically, however, it is in such periods, when social and economic conditions are at their worst, that the best opportunities appear.
During the transition between paradigms, the two main windows of opportunity open simultaneously: phase 1 , that of the new technologies, and phase 4 , that of the mature technologies (figure 10).

Although mature products can serve to provide growth for a certain length of time, they are not capable of driving a process of catching up, because their innovation potential is largely exhausted. During paradigm transitions, however, there is an excellent opportunity for making a leap forward. The new generic technologies and organizational principles can be applied in order to modernize and rejuvenate mature technologies (and even traditional technologies), as occurred, for example, in the automobile industry and other sectors in Japan, the shipbuilding and steel industries in South Korea, surgical instruments in Pakistan (Nadvi, 1999), and exports of fresh flowers from Colombia and fresh salmon from Chile. ${ }^{8}$ During the transition, it is also possible to try to enter the new industries directly, as many firms in developing countries did in the case of microelectronic products and software. The problem is then how to pass successfully through phases 2 and 3. Many of the bright early stars disappeared in this attempt. Staying in the

\footnotetext{
${ }^{8}$ These and other examples are described in ECLAC (1990).
}

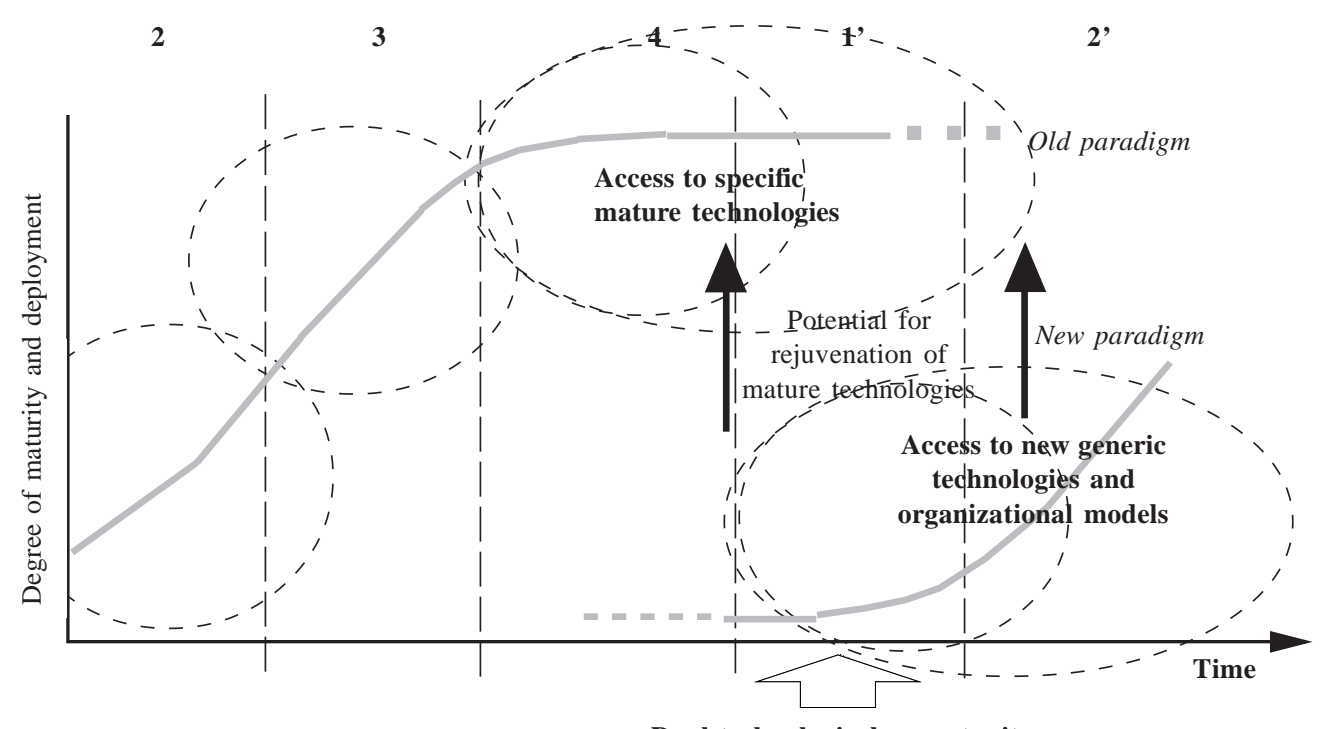

Dual technological opportunity 
race requires growing support from the economic environment, constant innovation, capital-intensive investments and, probably, great maneuverability as regards markets and alliances. Memory chips in South Korea, hard drives in Singapore, and the Asian computer clones are examples of this type of success, although in very specific conditions in each case.

In this specific paradigm transition, a very strong third possibility appeared within the context of globalization. In contrast with how the industries of the mass production paradigm were deployed nationally first, before moving internationally, many industries in this paradigm have operated globally from phase one. This has opened up the possibility of participating in global networks in many roles and with varied arrangements (Hobday, 1995; Radosevic, 1999). It has also allowed producing locally for export through global trading companies, either as single firms or by organizing cooperating clusters. ${ }^{9}$

\section{2. "Dancing with wolves" 10 or the question of power structures}

In order to fully understand the conditions of access to technology, it is necessary to consider the power structures. The changing nature of barriers to entry is closely related to the levels and forms of competition and concentration in the industry in question. The nature of each phase marks the behaviour of the firms involved and gradually modifies their main focus of attention and their interests.

Table 1 presents a stylized summary of the changing patterns of competition and power structures, which may typify evolving industries, their technologies and markets. It also indicates the "size" of the window of opportunity in each phase and the conditions that must be fulfilled by aspiring entrants, be they dependent (i.e., joining the strategy of owner firms) or acting autonomously as direct challengers in the market.

This stylized scheme cannot represent all cases, nor is it possible, in this brief article to examine all the variations and subtleties involved. The table can serve, however, as a frame of reference for making some important observations:

i) Since there will always be products and industries passing through the different phases, it is necessary to be conscious and well-informed about the phase

\footnotetext{
9 Schmitz and Knorringa (1999) and Schmitz and Nadvi (1999). See also IDS Collective Efficiency Research Project (2001).

${ }^{10}$ Used in a similar sense by Mytelka (1994).
}

of evolution of the specific technologies and about the patterns of competition prevailing in the various market segments, in order to be able to identify the interests of possible allies or competitors and assess their strengths. This process will also be useful for estimating the value of the assets and possibilities of one's own firm, in order to improve the decision-making process and the design of negotiating strategies.

ii) It is also important to identify the current phase of deployment of the technological revolution. Since such revolutions involve the co-evolution of many different systems, during the first decades of their deployment there will be prevalence of important new technologies in phases 1 and 2, whereas in subsequent decades the technologies approaching maturity phases (3 and 4) will predominate, until they overlap with those of the next transition. Thus, the windows of opportunity of each technology are strongly marked by the broader context of the propagation of the paradigm. This affects the strategies of both businesses and countries.

iii) Finally, the choice between dependent or autonomous entry is determined to a large extent by the conditions of the particular firm. It is also necessary to know the evolution of the power structures, in order to clearly identify the present and future interests of possible partners or competitors. The weaker the firm, the more important it is to learn to dance with powerful "wolves" (and even to distinguish among wolves and discover how to attract them).

Not all technologies are open to negotiation, of course. It may also happen that confrontation will be necessary in a zero-sum game. What must be avoided is to negotiate mutually beneficial agreements as though they were confrontations. It is ingenuous to think that through import substitution or export promotion policies governments were imposing conditions and restrictions on transnational corporations or obliging them to establish operations in the countries in question. In both cases, what was being negotiated in practice was a framework of regulations and incentives which solved the problems of both parties simultaneously. This indicates that, if the interests and needs of possible allies are clearly identified each time, the danger of aiming at the wrong target will be avoided, and negotiations will be based on a full awareness of the value of one's own competitive advantages. 


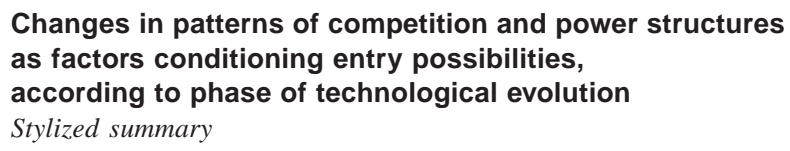

\begin{tabular}{|c|c|c|c|c|}
\hline & \multicolumn{4}{|c|}{ Phase in life cycle of product and its technology } \\
\hline & 1. Introduction & 2. Early growth & 3. Late Growth & 4. Maturity \\
\hline $\begin{array}{l}\text { Focus: compe- } \\
\text { titive factors }\end{array}$ & $\begin{array}{l}\text { Quality of product; } \\
\text { the test of the market }\end{array}$ & $\begin{array}{l}\text { Efficiency of production; } \\
\text { access to market }\end{array}$ & $\begin{array}{l}\text { Market scale and } \\
\text { power }\end{array}$ & Lower costs \\
\hline $\begin{array}{l}\text { Competition } \\
\text { and power }\end{array}$ & $\begin{array}{l}\text { Many new competitors } \\
\text { Unpredictable results }\end{array}$ & $\begin{array}{l}\text { Industry taking shape; } \\
\text { firms growing and } \\
\text { fighting for markets; } \\
\text { Emergence of leaders }\end{array}$ & $\begin{array}{l}\text { Tendency to concentration; } \\
\text { giant complex structures; } \\
\text { oligopolies, cartels, etc. }\end{array}$ & $\begin{array}{l}\text { Financial power. Search } \\
\text { for profitable new } \\
\text { opportunities and ways } \\
\text { of extending the life of } \\
\text { the existing ones }\end{array}$ \\
\hline \multicolumn{5}{|c|}{ AUTONOMOUS ENTRY } \\
\hline Size of window & Broad & Narrow & Very narrow & Widening \\
\hline $\begin{array}{l}\text { Basis for } \\
\text { attempting } \\
\text { autonomous } \\
\text { entry }\end{array}$ & $\begin{array}{l}\text { Knowledge: capacity to } \\
\text { imitate and innovate } \\
\text { (without infringing } \\
\text { patents) on local technical } \\
\text { know how in order to } \\
\text { create a specialized niche }\end{array}$ & $\begin{array}{l}\text { Knowledge plus experience } \\
\text { in process and market } \\
\text { technology (importance of } \\
\text { brands or privileged access } \\
\text { to market) }\end{array}$ & $\begin{array}{l}\text { Experience, financial } \\
\text { power and control of market }\end{array}$ & $\begin{array}{l}\text { Comparative advantages } \\
\text { in terms of costs } \\
\text { Learning capacity } \\
\text { Capacity to copy }\end{array}$ \\
\hline $\begin{array}{l}\text { Nature of } \\
\text { autonomous } \\
\text { entry (initiated } \\
\text { by challengers) }\end{array}$ & $\begin{array}{l}\text { Free competition to gain } \\
\text { acceptance in the market } \\
\text { and perhaps to establish } \\
\text { the dominant design; } \\
\text { patents can be important } \\
\text { here }\end{array}$ & $\begin{array}{l}\text { Aggressive competition for } \\
\text { growing, highly profitable } \\
\text { markets } \\
\text { Possible alliances }\end{array}$ & $\begin{array}{l}\text { Absorption or exclusion of } \\
\text { the weakest participants } \\
\text { Possible formation of } \\
\text { cartels }\end{array}$ & $\begin{array}{l}\text { Competition with other } \\
\text { low-cost producers; } \\
\text { purchase (or copying) of } \\
\text { mature technologies and } \\
\text { know how or development } \\
\text { of rejuvenatory innovations }\end{array}$ \\
\hline \multicolumn{5}{|l|}{ DEPENDENT ENTRY } \\
\hline Size of window & Narrow & Very narrow & Widening & Very broad \\
\hline $\begin{array}{l}\text { Basis for } \\
\text { negotiating } \\
\text { dependent } \\
\text { entry }\end{array}$ & $\begin{array}{l}\text { Comparative or dynamic } \\
\text { advantages; } \\
\text { complementary assets }\end{array}$ & $\begin{array}{l}\text { Attractive market } \\
\text { Competition as a supplier } \\
\text { or advantageous access } \\
\text { to resources or markets }\end{array}$ & $\begin{array}{l}\text { Large market } \\
\text { Externalities that already } \\
\text { exist or can be created; other } \\
\text { ways of promoting gains }\end{array}$ & $\begin{array}{l}\text { Comparative advantages } \\
\text { in terms of costs } \\
\text { Access to finance } \\
\text { Learning capacity }\end{array}$ \\
\hline $\begin{array}{l}\text { Nature of entry } \\
\text { on a dependent } \\
\text { basis or in } \\
\text { alliance with } \\
\text { another firm } \\
\text { (usually initiated } \\
\text { by owner of the } \\
\text { latter) }\end{array}$ & $\begin{array}{l}\text { Alliances; negotiations } \\
\text { on mutual benefits of } \\
\text { sharing complementary } \\
\text { capacity and/or assets } \\
\text { (in order to strengthen } \\
\text { potential for competition) }\end{array}$ & $\begin{array}{l}\text { As a supplier or trade } \\
\text { representative }\end{array}$ & $\begin{array}{l}\text { As part of the structure (as a } \\
\text { supplier, producer, } \\
\text { distributor or in any other } \\
\text { capacity which serves the } \\
\text { power strategy and expansion } \\
\text { plans of the more powerful } \\
\text { firm) }\end{array}$ & $\begin{array}{l}\text { Production contracts or } \\
\text { joint ventures of mutual } \\
\text { benefit (transfer of mature } \\
\text { technologies and market } \\
\text { access) }\end{array}$ \\
\hline
\end{tabular}

Historically, processes of rapid growth and development ?whether catching up from behind or forging ahead to the front ranks? have been the fruit of well-managed technological development processes (Lall, 1992; Bell and Pavitt, 1993a; Reinert, 1994;
Freeman, 1994; Von Tunzelmann, 1995). Generally speaking, they have been based on playing successive positive-sum games with the most advanced actors and on being prepared to change the game as the context and the structures evolve. 


\section{Accumulated experience and future}

\section{windows of opportunity}

Looking back at the recent history of the developing world and the different strategies applied, we see that, consciously or intuitively, successive positive-sum games were established between the interests of the advanced country firms and those of the developing nations. Analysis of this experience could help to view the future with more soundly based criteria. As always happens with the lessons of history, however, a distinction must be made between recurrence and uniqueness. There are patterns of change which are repeated in each paradigm, but each of them is essentially unique and must be analysed in the light of its own peculiar characteristics.

\section{Inventing and reinventing development strategies}

The modern era of deliberate State intervention in the industrialization of Third World countries took shape clearly in the 1950s, when a growing number of mass production industries were in phase 3 , trying to expand markets, seeking economies of scale, forming oligopolies, and opening international marketing outlets. Import substitution industrialization, subsidized by the State and protected by tariff barriers, was the positive-sum game that was established at that time. The international corporations multiplied their markets for final products by exporting much greater amounts of "unassembled" parts to their subsidiaries abroad, which in addition had higher profit margins. In the developing countries, for their part, although those factories only engaged in "screw-driver assembly" activities, they and the enterprises and organizations stimulated by their demand created a learning context for both management and workers. Their demand for construction services, highways, ports, transport, electricity, water and communications stimulated the modernization of the surrounding areas and the development of many complementary capabilities.

In the mid-1960s, some countries began to encounter the limits of the import substitution industrialization model, while in the advanced countries many products and industries were entering phase 4 : maturity and stagnation. Technology transfer and export promotion policies emerged as the new form of relations of mutual benefit. This process entailed the transfer of mature technologies to public and private enterprises, as well as the establishment of subsidiaries to produce goods for re-export, in areas with cheap labour. Already by the 1970 s, the transnational corporations were engaged in the process of industrial redeployment, whereby they transferred a growing proportion of their production activities to developing countries, thus giving rise to a substantial flow of exports to the advanced countries. The "miracles" of Brazil and South Korea and the "export-processing zones" in many countries gave the impression that a new international economic order was arising. The North-South Dialogue was set up to negotiate the realization of those hopes.

At the beginning of the 1980s, however, the situation changed once again. Many of the products of the microelectronics revolution, which had irrupted in the early 1970s, were reaching phase 2 . Furthermore, the Japanese had revitalized the automobile industry and their new organizational paradigm was radically transforming their competitors in the United States and Europe (Altshuler and others, 1984). Most of the old industries of the advanced countries reached the maturity stage in the midst of stagflation; export markets began to shrink, and the debt crisis broke out in the Third World. A new strategy needed to be designed.

Most of Latin America, however, failed to do so, and lived through the aptly designated "lost decade". In contrast, the Four Tigers in Asia took a leap forward by capturing position after position in the rear end and at the edges of the markets of the fast growing revolutionary industries. They also rejuvenated mature technologies with modern practices and joined the networks of global firms as OEM suppliers of parts and components. The intense learning and the emphasis on human capital and on the active absorption of technology, which was behind these achievements, cannot be overstated (Amsden, 1989: Ch. 9; Bell and Pavitt, 1993b). It is in sharp contrast with the much 
more passive "transfer of technology" practices still common in most Latin American and African countries, as well as in the rest of Asia, in that period.

Figure 11 shows, from the 1950s to the present, how development strategies adapted to the opportunities created by the approaching maturity of one paradigm and the initial deployment of the next.

The 1990s was marked by the vigorous development of the new telecommunications infrastructure, by the structuring of the emerging industries and the modernization of the existing ones. As one new industry after another reached phase 2, the intense competition for market positions began. Since then, various possibilities have arisen for the enterprises of developing countries, due to a set of new phenomena such as: the emergence of global corporations and markets, the struggles to impose dominant designs and other standards, the establishment of complex networks of collaboration at the world level, the strengthening of the power of brand names in the market, the pursuit of both dynamic and static advantages in the geographical location of the various activities, the interest in adapting products to particular market segments, the tendency towards outsourcing, and other related forms of behaviour. The quality and quantity of the opportunities deriving from all this have varied as a function of the conditions and disposition of the different economic agents and of the countries in which they operate.

Experimentation in the developing countries has been very diversified, both in terms of methods and of results: it extends from modern "maquiladoras" and OEM contracts to the practices followed by independent and highly competitive Asian firms and various types of joint ventures and alliances (Hobday, 1994). There has also been a big increase in interconnected local clusters in specific industries (such as software development in India), some of which have been successful on export markets. In this period, the four "Asian tigers" continued to progress, stimulating production in other Southeast Asian countries and China. Generally speaking, the countries and firms with successful strategies have displayed a capacity to learn to live in a globalized world.

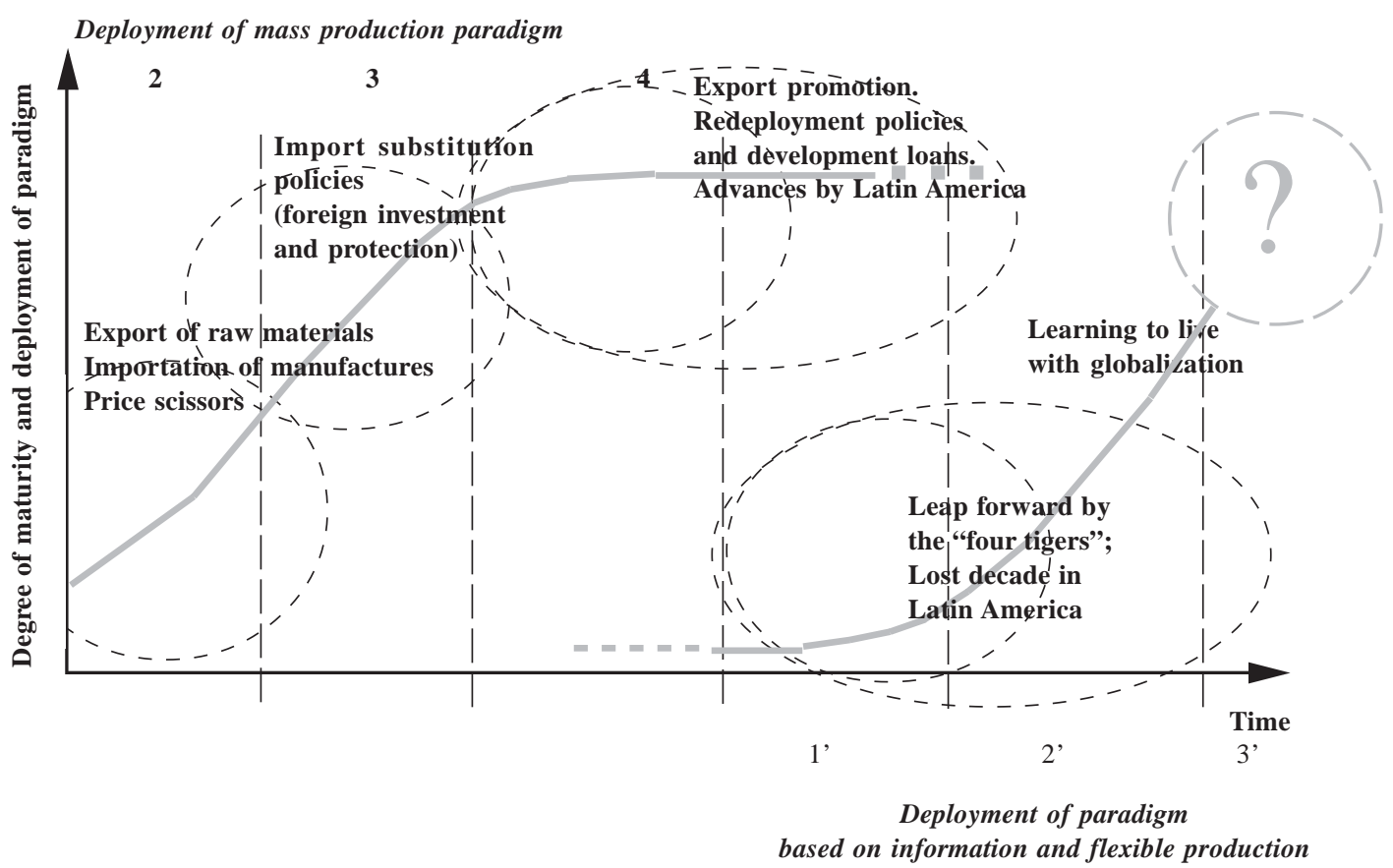

TECHNOLOGICAL CHANGE AND OPPORTUNITIES FOR DEVELOPMENT AS A MOVING TARGET • CARLOTA PÉREZ 
Each of the successive strategies has had advantages and disadvantages, benefits and negative effects. Some countries have advanced with giant strides, while others have taken only small steps forward or have not advanced at all; some countries kept the ground gained, while others have fallen back. Some of the setbacks may have been due to having clung to policies which had ceased to be effective. It must be admitted that the general results are discouraging. This may lead to disenchantment or else to recognition of the great difficulty of narrowing the gap and the need for a better understanding of the nature of the problems and the opportunities.

\section{Confronting the next stage}

Sooner or later in this new century, the conditions will be created for the full deployment of the wealthgenerating potential of the Information Age. The 1990s were years of experimentation in all areas: inside and outside global firms; in countries, regions, cities and localities; in the economy; in governments and other institutions, and in the different levels of society. Consequently, the "common sense" of the flexible networks paradigm has been widely disseminated and is becoming the normal way of seeing and doing things.

The dawn of the 21 st century marks the transition to the third phase or period of late growth of the present paradigm. ${ }^{11}$ Many industries are also reaching phase 3 in their trajectories, so they are seeking economies of scale and moving towards oligopolization in order to reduce the pressures of free competition. Agreements, mergers, takeovers and other arrangements are giving rise to the world-level concentration of many important industries into a few mega-enterprises or great global alliances. ${ }^{12}$ Indeed, their growing power of intermediation, through their control of access to clients, could lead to a modern version of the old "trading companies", based now on the power of information and telecommunications. ${ }^{13}$ These gigantic enterprises could become immense global "umbrellas" encompassing worldwide diversity in their field and covering all the segments of the market ?from the most specialized or luxury niches to the cheapest and most standardized products or services? buying and selling all over the planet and locating each activity where it enjoys the greatest advantages.

For the developing world, the next stage may be a very complex period of accommodation to the new emerging power structures. For enterprises, localities, regions and countries, finding out what positive-sum games are possible with these giants could define the nature of their next window of opportunity. Trying to create local or regional networks, either independently or in association with global networks, may still be possible when there are very specific local advantages. Countries and enterprises which have acquired technological, organizational, marketing and bargaining capabilities will of course be in a much better position either to find a favourable arrangement under the global "umbrellas" or to boldly establish themselves outside them. Cooperation among enterprises, regions or countries can increase the bargaining power of their leading actors and agents, both weak and strong.

The formulation of successful strategies therefore calls for a careful evaluation of the conditions and accumulated capacities of the country, region, enterprise or network in question, in order to take advantage of the next window of opportunity (not the window which is already closing), while at the same time recognizing, adopting and adapting the potential and features of the relevant paradigm. We will now look at some of the implications of these features.

\footnotetext{
${ }^{11}$ For a more complete analysis of the phases in the evolution of a paradigm and the role played by financial capital in the process, see Pérez, 2002.

12 See Chesnais (1988 and 1992), Bressand (1990), Klepper and Kenneth (1994) and Castells (1997).

${ }^{13}$ See Bressand and Kalypso (eds.) (1989), and Kanellou (2000).
} 
VI

\section{Addressing development in the context of the present paradigm}

Rapid growth of firms, localities or countries depends on the availability of a rich technological potential and a suitable form of organization for taking advantage of it. Whatever the starting point and the objective pursued, success in the present era will probably depend on how deeply the logic of the new paradigm is assimilated and how creatively it is adopted and adapted at all levels of society.

The old centralized pyramids of mass production effectively served firms and governments, universities, hospitals, and private and public organizations of all types. For over twenty years, however, modern firms -global or local- have been thoroughly restructuring their activities, having quickly understood the advantages of networks and of learning organizations. ${ }^{14}$ The time has now come for governments to start experimenting in the same direction.

\section{Technology at the core of development strategies}

It is a generally recognized fact that the Japanese surge ahead to become the second largest economy in the world (and to remain in that position in spite of its crisis) involved exercises in technological foresight to collectively decide the road to follow, as well as intensive learning, training and innovative efforts (Peck and Goto, 1981; Irvine and Martin, 1985). The advance of the four "Asian tigers" from their initial position in the rear also involved a large-scale educational and learning effort (Ernst, Ganiatsos and Mytelka (eds.), 1998). Furthermore, the global enterprises which have been successful have reformulated their structures and practices to promote continuous learning and improvement. Knowledge management (Nonaka, 1995; Burton-Jones, 1999; Lamoreaux and others (eds.), 1999) is becoming a fundamental concern: enterprises not only organize regular training courses at all levels, but some have even created their own "universities" (Wiggenhorn, 1990).

\footnotetext{
${ }^{14}$ Nonaka (1994), Senge (1990) and Lundvall (1997); see also the website of the DRUID project (DRUID, 2001).
}

In the case of the developing countries, it is an illusion to believe that significant advances are possible without equivalent efforts. There are no magic formulas for achieving development without mastering technology, in the simple sense of social, technical and economic know-how incorporated in people. This fact, which was fully recognized in the past, was lost from sight in the very special conditions of import substitution policies, which made it possible -for a time- for many countries to achieve extraordinary results in terms of growth, by investing in mature installations, equipment and technologies without having to make intensive learning and training efforts.

In this new paradigm, in particular, development of the capacity to take advantage of information and knowhow for innovation is more important than ever. Perhaps the most relevant sense of the expression "knowledge society" (Castells, 1997; Mansell and Wehn (eds.), 1998) is the creation of conditions for all members of society to have access to information and make use of it. Consequently, strengthening the individual and social learning capabilities for wealth generation becomes a fundamental way of enhancing development potential.

For this to take place, technology must occupy a central and not just a peripheral place in development policies. In practice, this means adopting a different way of conceiving strategies and calls for a complete reformulation of the education and training systems as well as of science and technology policies.

In reforming education, it is essential to update and upgrade the technical contents of programmes and -perhaps even more importantly- to make radical changes in the methods, objectives and instruments of training in order to make them relevant for the future and compatible with the new forms of organization (Pérez, 1992 and 2000; ECLAC, 1992). This reform must induce students to take responsibility for their own training processes; it must place emphasis on "learning to learn" and "learning to change"; it must foster creative teamwork, teaching students to formulate problems and evaluate alternative solutions; it must find ways of providing access to computers and the Internet; and it must create the 
necessary conditions for giving students not so much the capacity to provide answers as the capacity to ask questions and process information.

These skills and aptitudes are becoming basic conditions for participating in the modern workplace, where firms are facing a constantly evolving environment that demands continuous improvement. They also allow persons and groups to become responsible for their own capacity to generate wealth, either as employees or as entrepreneurs, and they provide the organizational abilities needed to improve communities and organizations, either as group members or as leaders.

The other vital transformation concerns the "Science and Technology System", which was created in most developing countries as a set of government institutions responsible for technological development. Experience showed that very little use was made of these capabilities to incorporate innovations in the world of production. As most of the industries were using mature technologies, they had little capacity to absorb the results of the activities of these laboratory technologists. The consequent frustration experienced when trying to "build a bridge" between the universities and industry led most of the technological researchers to become adjuncts of the scientific community and to adopt its methods, time-scales, values and attitudes.

In the new context, it is necessary to act on two fronts: to make substantial investments in research for the future, and to re-connect the technological development effort with the direct and immediate improvement of production networks and the quality of life.

This transition from a "supply-push" science and technology system to an interactive network with producers has warranted the term "National System of Innovation (NSI)" (Freeman, 1987; Lundvall, 1988) which has been defined by Freeman as "the network of institutions in the public and private sectors whose activities and interactions initiate, import, modify and diffuse new technologies" (Freeman, 1995).

This starts out from the assumption that a national system of innovation is a social, not a governmental construction. It includes such elements as the environment in which innovation is stimulated and supported; the quality of the links between suppliers, producers and users; the education and training system; various public and private organizations facilitating technical change; and laws, regulations and even ideas and attitudes towards technology and change (Arocena, 1997).

\section{Reinventing the "strong" State ${ }^{15}$}

It should by now be clear that the market versus State debate is not adequate for dealing with the concrete problems discussed here. Both markets and State are needed, albeit redefined and combined in a new way. At all events, it will be gathered from the foregoing analysis that a successful development strategy for a lagging country will require, according to the logic of the current paradigm (and especially in the presence of global mega-firms), a high level of cooperation among firms and between them and the State at its various levels.

Although the magnitude and complexity of this task call for a strong State, the type of all-powerful State developed after World War II must be redefined and reinvented, probably along similar lines to those applied by modern global corporations.

No one could suggest that the central management of a giant corporation is weakened by decentralizing and giving high autonomy and decision-making power to its product, plant or market managers across the world. Computers and telecommunications have made it easier to exercise strong leadership over a vast and growing structure made up of semi-autonomous units following strategic guidelines. Thanks to interactive information channels, it is possible to monitor and control extremely complex networks which have flexible components and are highly differentiated.

Such networks could be imitated in the new configuration of a strong public sector which is needed. As in previous technological revolutions, once technology helps to define the optimum configuration of organizations, these can function effectively even without the technology. In turn, this prepares the terrain for the incorporation of modern technology when required.

The central national State can exercise its leadership by inducing the convergent actions of the various social actors towards a commonly agreed general direction of change. It can play a crucial role as intermediary between the growing global or supraregional instances and the increasingly autonomous regional, local and even parish or community levels.

A process of "diffusion of power" is also taking place (Strange, 1996). Networks of private interests,

${ }^{15}$ See Reinert (1999), Wade (1990) and Osborne and Gaebler (1994). 
the various components of civil society, global firms, the media, organized interest groups, non-governmental organizations (NGOs) and other entities are increasing the diversity of development agents and their interconnections, at both the national and global levels. The State must be capable of acting as a broker within the country and between the different supra-national and subnational levels, in order to promote and negotiate equitable opportunities for all. Taking on the role of consensus builder among the different actors, the State may be able to exercise more effective authority, as the foundation of real power to influence the course of events.

\section{Think global, act local}

The new seat of the proactive developmental state is, in our view, the local government. The old "central plan" idea of promoting a set of national industries to generate the wealth to fund social advance needs to be reconsidered. Obviously, in each country a set of important and competitive activities must develop, strongly connected to world markets and keeping up with the technological frontier, propelling growth and producing the necessary foreign exchange. But that is not enough. The time and the conditions have come to abandon the illusion of a "trickle down effect" and move towards the direct involvement of the whole population in wealth creating activities.

The characteristics of the present paradigm suggest that there will be a more integrated form of development in which the big, competitive industries trading on the world market will be complemented with the differentiated development of each part of the territory. This is possible by taking advantage of the new flexibility in terms of variety of products and competitive scales of production, of the power to increase the quality and efficiency of all sectors and activities (including artisan type activities) and -most important- the fact that all human beings can be given access to continuous learning processes in order to constantly improve their capabilities, their work and their environment.

Many examples can be cited of local governments identifying the production potential of their communities, promoting consensus and securing the participation of local and foreign firms, banks, the education system and other local and external agents in order to propel development projects (Tendler, 1997; Gabor, 1991; The Illinois Coalition, 1999). There are also local networks of small and medium-sized firms collaborating in business and technological development to cover exports jointly (Nadvi and Schmitz (eds.), 1999). Authors who have studied the interaction that takes place within these clusters, or agglomerations of firms with related activities in the same locality, have suggested using the expression "local systems of innovation" (Cassiolato and Lastres (eds.), 1999), although in our view it would be more appropriate to call them "territorial networks of innovativeness".

A highly successful experience has also been accumulated by specialized banks giving "microcredits" to help men and women in urban and rural areas to set up income generating activities (Otero and Rhyne (eds.), 1994; Chaves and González, 1996). This is gradually breaking the myth that providing jobs is the only way to improve the quality of life of whole populations and favouring the idea of promoting multiple forms of individual or collective entrepreneurship. Addressing the plight of rural communities will also require abandoning the old pro-urban and promanufacturing biases (Fieldhouse, 1986, p. 152; Mytelka, 1989) and empowering local governments with the resources and the technical support to directly tackle the issue of improving the local levels of living. These "localized" activities can often connect as suppliers in the networks of global corporations or become part of the support network of the big exporting activities of the country.

\section{Modernity and values}

Naturally, the decisions involved are of a political nature, but the real options are not always clear. Historically, in each transition from one paradigm to another the current definitions of left and right become blurred. Each of the groups undergoes an internal division between those who cling to old ways of achieving their goals and those that embrace the potential of the new paradigm and gear it to their ends (figure 12).

In the previous transition, between the two world wars, the social and homogenizing nature of the new mass production paradigm was so strong that even Nazism called itself "National Socialism". Likewise, the role played by the centralized State was so important that after World War II even the most liberal nations adopted the model of State intervention in the economy in its entirety, following the ideas of Keynes, 
which had met with so much resistance in the 1920s and 1930s. Unfortunately for those who are convinced of the need for social solidarity, however, neoliberalism is the only coherent programme that has adopted the present paradigm. Although there are thousands of isolated experiments in forward-looking practices such as participatory democracy and local consensus-building, no coherent experience or proposal has yet been put forward that could serve as a modern alternative to the pure market. Without it, in our view, there may be world growth, but there is probably little hope of a widespread surge in development.

(Original: Spanish)
FIGURE 12

\section{Political positions in the transition:}

A location matrix

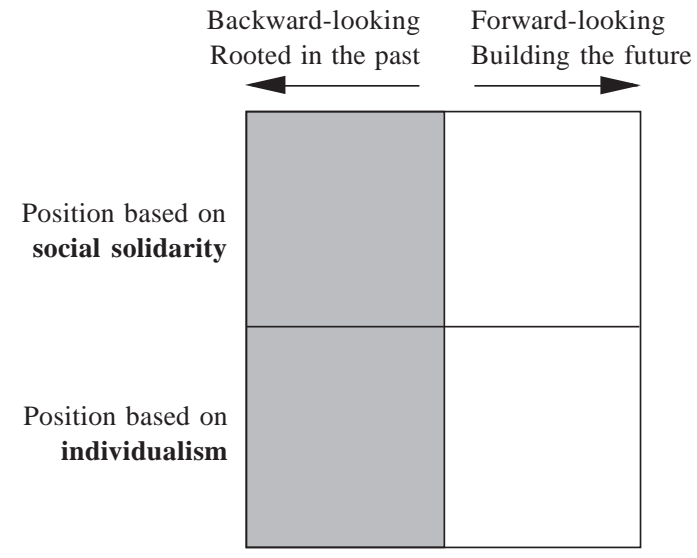

\section{Bibliography}

Abernathy, W. and J. Utterback (1975): A dynamic model of process and product innovation, Omega, vol. 3, No. 6.

Abramovitz, M. (1986): Catching up, forging ahead and falling behind, Journal of Economic History, No. 46.

Altshuler, A. and others (1984): The Future of the Automobile: The Report of MIT's International Automobile Program, Cambridge, Massachusetts, The MIT Press.

Amsden, A. (1989): Asia's Next Giant. South Korea and Late Industrialization, Oxford, U.K., Oxford University Press.

Arocena, R. (1997): Qué piensa la gente de la innovación, la competitividad, la ciencia y el futuro, Montevideo, Trilce.

Arthur, W. B. (1989): Competing technologies, increasing returns and lock-in by historical events, The Economic Journal, vol. 99, No. 394, Oxford, U.K., Basil Blackwell. Also published in Freeman (ed.), The Economics of Innovation, Aldershot, U.K., Edward Elgar Publishing, 1990.

Bell, M. and K. Pavitt (1993a): Technological accumulation and industrial growth: contrasts between developed and developing countries, Industrial and Corporate Change, vol. 2, No. 2, Oxford, U.K., Oxford University Press.

(1993b): Accumulating technological capability in developing countries, Proceedings of the World Bank Annual Conference on Development Economics, 1992, Washington, D.C., World Bank.

Bressand, A. (1990): Electronics cartels in the making?, Transatlantic Perspectives, No. 21.

Bressand, A. and N. Kalypso (eds.) (1989): Strategic Trends in Services: An Inquiry into the Global Service Economy, New York, Harper and Row.

Burton-Jones, A. (1999): Knowledge Capitalism: Business, Work and Learning in the New Economy, Oxford, U.K., Oxford University Press.

Cassiolato, J. and H. Lastres (eds.) (1999): Globalização \& inovação localizada. Experiencias de sistemas locais no Mercosul, Brasilia, Brazilian Institute of Scientific and Technological Information (IBICT).
Castells, M. (1996): The Information Age: Economy, Society and Culture, vol. 1, The Rise of the Network Society, Oxford, U.K., Basil Blackwell.

Chaves, R. and C. González (1996): The design of successful rural financial intermediaries: Evidence from Indonesia, World Development, vol. 24, No. 1, Oxford, U.K., Pergamon Press Ltd.

Chesnais, F. (1988): Multinational enterprises and the international diffusion of technology, in G. Dosi and others (eds.), Technical Change and Economic Theory, London, Pinter Publishers.

(1992): National systems of innovation, foreign direct investment and the operations of multinational enterprises, in B. Lundvall, National Systems of Innovation: Towards a Theory of Innovation and Interactive Learning, London, Pinter Publishers.

Coombs, R., P. Saviotti and V. Walsh (1987): Economics and Technological Change, London, Macmillan Educational Ltd.

Coriat, B. (1991): Penser à l'envers, Paris, Christian Bourgeois Editeur.

Cundiff, E. and others (1973): Fundamentals of Modern Marketing, Englewood Cliffs, New Jersey, Prentice-Hall.

David, P. (1985): Clio and the economics of QWERTY, The American Economic Review, vol. 75, No. 2, Nashville, Tennessee, American Economic Association. Also published in Freeman (ed.), The Economics of Innovation, Aldershot, U.K., Edward Elgar Publishing, 1990.

Dosi, G. (1982): Technological paradigms and technological trajectories. A suggested interpretation of determinants and directions of technical change, Research Policy, vol. II, No. 3, Amsterdam, The Netherlands, North-Holland.

(1988): Sources, procedures, and macroeconomic effects of innovation, Journal of Economic Literature, vol. XXVI, No. 3, Nashville, Tennesse, American Economic Association. Also published in Freeman (ed.), The Economics of Innovation, Aldershot, U.K., Edward Elgar Publishing, 1990. 
Dosi, G. (ed.) (1988): Technical Change and Economic Theory, London, Pinter Publishers.

DRUID (Danish Research Unit on Industrial Dynamics) (2001): A The Firm as a Learning Organization. (http:// www.business.auc.dk/druid).

ECLAC (Economic Commission for Latin America and the Caribbean) (1990): Changing Production Patterns with Social Equity, LC/G.1601-P, Santiago, Chile. United Nations publication, Sales No. E.90.II.G.6.

(1992): Education and Knowledge: Basic Pillars of Changing Production Patterns with Social Equity, LC/G.1702/ Rev.2-P, Santiago, Chile, August.

Ernst, D., T. Ganiatsos and L. Mytelka (eds.) (1998): Technological Capabilities and Export Success in Asia, London, Routledge.

Fagerberg, J. and others (eds.) (1994): The Dynamics of Technology, Trade and Growth, Aldershot, U.K., Edward Elgar Publishing.

Fieldhouse, D. (1986): Economic Decolonisation and Arrested Development, London, George Allen.

Freeman, C. (1974): The Economics of Industrial Innovation, Harmondsworth, Middlesex, U.K., Penguin Books Ltd. (1987): Technology Policy and Economic Performance: Lessons From Japan, London, Pinter Publishers.

(1994): Technological revolutions and catching up: ICT and the NICs, in J. Fagerberg and others (eds.), The Dynamics of Technology, Trade and Growth, Aldershot, U.K., Edward Elgar Publishing.

(1995): The national system of innovation in historical perspective, Cambridge Journal of Economics, vol. 19, No. 1, Cambridge, U.K., Academic Press Limited.

Freeman, C. (ed.) (1990): The Economics of Innovation, Aldershot, U.K., Edward Elgar Publishing.

Freeman, C., J. Clark and L. Soete (1982): Unemployment and Technical Innovation. A Study of Long Waves and Economic Development, London, Frances Pinter Publishers.

Freeman, C. and F. Louçã (2001): As Time Goes By: From the Industrial Revolutions to the Information Revolution, Oxford, U.K., Oxford University Press.

Freeman, C. and C. Pérez (1988): Structural crises of adjustment: Business cycles and investment behaviour, in G. Dosi and others (ed.), Technical Change and Economic Theory, 3rd edition, London, Pinter Publishers.

Freeman, C. and L. Soete (1997): The Economics of Industrial Innovation, London, Pinter Publishers.

Gabor, A. (1991): Rochester focuses: A community's core competence, Harvard Business Review, Boulder, Colorado, Harvard University, July-August.

Gerschenkron, A. (1962): Economic Backwardness in Historical Perspective, Cambridge, Massachusetts, Harvard University Press.

Grübler, A. (1990): The Rise and Fall of Infrastructures. Dynamics of Evolution and Technological Change in Transport, Heidelberg, Physica-Verlag.

Hirsch, S. (1965): The United States electronic industry in intenational trade, National Institute Economic Review, No. 34 .

(1967): Location of Industry and International Competitiveness, Oxford, U.K., Clarendon Press.

Hobday, M. (1994): Export-led technology development in the Four Dragons: The case of electronics, Development and Change, vol. 25, No. 2, The Hague, The Netherlands, Institute of Social Studies.
(1995): Innovation in East Asia: The Challenge to Japan, Aldershot, U.K., Edward Elgar Publishing.

Hoffman, K. and H. Rush (1988): Microelectronics and the Clothing Industry, New York, Praeger.

IDS Collective Efficiency Research Project (2001): (http:// www.ids.ac.uk/ids/global/coleff.html)

Irvine, J. and B. Martin (1985): Foresight in Science Policy: Picking the Winners, London, Pinter Publishers.

Jang-Sup, S. (1992): Catching up and technological progress in late-industrializing countries, Cambridge, Massachusetts, Cambridge University, Master's thesis.

Kanellou, D. (2000): The new role of intermediaries in travel and tourism distribution channels, IPTS (Institute for Prospective Technology Studies), No. 48, pp. 12-22, Seville, Spain.

Katz, J. (ed.) (1996): Estabilización macroeconómica, reforma estructural y comportamiento industrial; estructura y funcionamiento del sector manufacturero latinoamericano en los años 90, Buenos Aires, Alianza Editorial.

Klepper, S. and S. Kenneth (1994): Technological change and industry shakeouts, paper presented at the Fifth Conference of the International Joseph A. Schumpeter Society, Münster, August.

Kotler, P. (1980): Principles of Marketing, Englewood Cliffs, New Jersey, Prentice-Hall.

Lall, S. (1992): Technological capabilities and industrialization, World Development, vol. 20, No. 2, Oxford, U.K., Pergamon Press.

Lamoreaux, N. and others (eds.) (1999): Learning by Doing in Markets, Firms and Countries, Cambridge, Massachusetts, National Bureau of Economic Research (NBER).

Leontief, W. (1954): Domestic production and foreign trade: The American capital position re-examined, Economia internazionale, vol. 7, No. 1, Genoa, Italy, Istituto di Economia Internazionale.

Lundvall, B. (1988): Innovation as an interactive process: From user-producer interaction to the national system of innovation, in G. Dosi and others (ed.), Technical Change and Economic Theory, London, Pinter Publishers.

(1992): National Systems of Innovation: Towards a Theory of Innovation and Interactive Learning, London, Pinter Publishers.

(1997): Information technology in the learning economy: Challenges for development strategies, Communications \& Strategies, No. 28.

Mansell, R. and U. Wehn (eds.) (1998): Knowledge Societies: Information Technology for Sustainable Development, Oxford, U.K., Oxford University Press.

Mytelka, L. (1989): The unfulfilled promise of African industrialization, African Studies Review, vol. 32, No. 3.

(1991): New models of competition in the textile and clothing industry: Some consequences for third world exporters, in J. Niosi (ed.), Technology and National Competitiveness, Montreal, Canada, McGill-Queen's University Press.

(1994): Dancing with wolves: Global oligopolies and strategic partnerships, in J. Hagedoorn (ed.), Technical Change and the World Economy. Convergence and Divergence in Technology Strategies, Aldershot, U.K., Edward Elgar Publishing.

Nadvi, K. (1999): The cutting edge: collective efficiency and international competitiveness in Pakistan, Oxford Development Studies, vol. 27, No. 1. 
Nadvi, K. and H. Schmitz (eds.) (1999): Industrial clusters in developing countries, World Development, vol. 27, special issue, Oxford, U.K., Pergamon Press Ltd.

Nonaka, I. (1994): Dynamic theory of organizational knowledge creation, Organizational Sciences, vol. 5, No. 1, February.

(1995): The knowledge-creating company: How Japanese companies create the dynamics of innovation, Harvard Business Review, Boulder, Colorado, Harvard University, November-December.

Osborne, D. and T. Gaebler (1993): Reinventing Government: How the Entrepreneurial Spirit is Transforming the Public Sector, New York, Plume Penguin.

Otero, M. and E. Rhyne (eds.) (1994): The New World of Microenterprise Finance. Building Healthy Financial Institutions for the Poor, West Hartford, Connecticut, Kumarian Press.

Peck, J. and A. Goto (1981): Technological and economic growth: The case of Japan, Research Policy, vol. 10, Amsterdam, The Netherlands, Elsevier Science Publishers B.V.

Pérez, C. (1983): Structural change and the assimilation of new technologies in the economic and social systems, Futures, vol. 15, No. 5, Surrey, U.K., IPC Science and Technology Press UK.

(1985): Microelectronics, long waves and world structural change: New perspectives for developing countries, World Development, vol. 13, No. 3, Oxford, U.K., Pergamon Press Ltd.

(1986): Las nuevas tecnologías: una visión de conjunto, in C. Ominami (ed.), El sistema internacional y América Latina. La tercera revolución industrial: impactos internacionales del actual viraje tecnológico, Buenos Aires, Grupo Editor Latinoamericano.

(1992): New technological model and higher education: a view from the changing world of work, in G. López Ospina (ed.), Challenges and Options: Specific Proposals, Caracas, United Nations Educational, Scientific and Cultural Organization (UNESCO).

(1996): La modernización industrial en América Latina y la herencia de la sustitución de importaciones, Comercio exterior, vol. 46, No. 5, Mexico City, Banco Nacional de Comercio Exterior, S.N.C.

(2000): La reforma educativa ante el cambio de paradigma, Caracas, UCAB-Eureka

(2002): Technological Revolutions and Financial Capital: The Dynamics of Bubbles and Golden Ages, Cheltenham, U.K., Edward Elgar Publishing.

Pérez, C. and L. Soete (1988): Catching up in technology: Entry barriers and windows of opportunity, in G. Dosi and others (ed.), Technical Change and Economic Theory, London, Pinter Publishers.

Peters, T. (1989): Thriving on Chaos: Handbook for a Management Revolution, London, Macmillan.
Porter, M.E. (1990): The Competitive Advantage of Nations, New York, The Free Press.

Radosevic, S. (1999): International Technology Transfer and Catchup in Economic Development, Massachusetts, Edward Elgar Publishing.

Reinert, E. (1994): Catching-up from way behind. A third world perspective on first world history, in J. Fagerberg and others (eds.), The Dynamics of Technology, Trade and Growth, Aldershot, U.K., Edward Elgar Publishing.

(1999): The role of the State in economic growth, Journal of Economic Studies, vol. 26, Nos. 4-5, West Yorkshire, U.K., MCB University Press Ltd.

Sahal, D. (1985): Technological guideposts and innovation avenues. Research Policy, vol. 14, No. 2, Amsterdam, The Netherlands, North-Holland.

Schmitz, H. and P. Knorringa (1999): Learning from Global Buyers, IDS working paper, No. 100, Sussex, U.K., University of Sussex, Institute of Development Studies.

Schmitz, H. and K. Nadvi (1999): Clustering and industrialization: Introduction, World Development, vol. 27, No. 9, Oxford, U.K., Pergamon Press Ltd.

Senge, P. (1990): The Fifth Discipline, New York, Doubleday.

Strange, S. (1996): The Retreat of The State. The Diffusion of Power in The World Economy, Cambridge, U.K., Cambridge University Press.

Tendler, J. (1997): Good Government in the Tropics, Baltimore, Maryland, The Johns Hopkins University Press.

The Illinois Coalition (1999): Technology and Jobs Agenda. A Vision and Plan for Technology-Based Economic Development in Illinois. (www.ilcoalition.org/tja.htm)

Vernon, R. (1966): International investment and international trade in the product cycle, Quarterly Journal of Economics, vol. 80, Cambridge, Massachussetts, Harvard University, May.

Von Tunzelmann, G. (1995): Technology and Industrial Progress. The Foundations of Economic Growth, Aldershot, U.K., Edward Elgar Publishing.

Von Tunzelmann, N. and E. Anderson (1999): Technologies and skills in long-run perspective, Sussex, U.K., University of Sussex, mimeo.

Wade, R. (1990): Governing the Market: Economic Theory of Government in East Asia Industrialization, Princeton, New Jersey, Princeton University Press.

Wells, L. (1972): International trade: The product life cycle approach, in L. Wells (ed.), The Product Life Cycle and International Trade, Boston, Harvard University, Graduate School of Business Administration, Division of Research.

Wiggenhorn,W. (1990): Motorola U: When training becomes an education, Harvard Business Review, vol. 68, No. 4, Boulder, Colorado, Harvard University, July-August.

Wolf, J. (1912): Die Volkswirtschaft der Gegenwart und Zukunft, A. Deichertsche Verlags-Buchandlung. 